Revista de Estudos da Linguagem, Belo Horizonte, v. 23, n.2, p. 335-361, 2015

\title{
Does the mental lexicon exist?
}

\section{O léxico mental existe?}

\section{Lucilene Bender de Sousa}

Pontíficia Universidade Católica do Rio Grande do Sul (PUCRS), Porto Alegre, Rio Grande do Sul, Brasil.

lenebender10@gmail.com

Rosangela Gabriel

Universidade de Santa Cruz do Sul (UNISC), Santa Cruz do Sul, Rio Grande do Sul, Brasil.

rgabriel@unisc.br

\begin{abstract}
One of the central and most intriguing components of language processing to researchers is the mental lexicon. The term was used for the first time by Ann Triesman in 1961 and we still do not have clear answers on how it is structured and how much information it contains, or even if there is something to be called a mental lexicon. For some time, the mental lexicon has been compared to a mental dictionary both storing and organizing word knowledge; however, they are surely different in structure and quantity / quality of information. Neuroimaging studies have also tried to bring contributions to these questions. Some researchers believe that there are many lexicons, one for each level of stored information (ULLMAN, 2007): orthographic, phonological, semantic and syntactic lexicons. Another group of researchers (MCCLELLAND; ROGERS, 2003; SEIDENBERG, 1997, etc.) postulates the existence of only one lexicon where all information levels are integrated. Recently, a new
\end{abstract}


audacious proposal has been done by Elman (2009), the inexistence of a mental lexicon. In this paper, we discuss the different views of the mental lexicon structure and content, in order to question the architecture of the lexical knowledge in the brain as opposed to what can be consciously thought as the speaker's lexical knowledge. We try to proceed on the discussion of Elman's new proposal and confront it to data obtained by behavioral, neuroimaging and computational studies. This theoretical review briefly explains the evolution of the mental lexicon conceptions from the dictionary-like to the no-lexicon proposal.

Keywords: linguistic knowledge; mental lexicon; network architecture; language processing; language description.

Resumo: Um dos componentes mais centrais e intrigantes do processamento da linguagem para os pesquisadores é o léxico mental. O termo foi usado pela primeira vez por Ann Triesman em 1961 e até o momento não temos respostas claras sobre como ele é estruturado e quanta informação contém, ou mesmo se existe algo a ser chamado de léxico mental. Durante algum tempo, o léxico mental foi comparado a um dicionário mental, responsável por armazenar e organizar o conhecimento de palavras; entretanto, certamente há distinções em termos de estrutura e quantidade / qualidade de informação armazenada. Alguns pesquisadores acreditam que existem vários léxicos, um para cada nível de informação (ULLMAN, 2007): léxico ortográfico, fonológico, semântico e sintático. Outro grupo de pesquisadores (MCCLELLAND; ROGERS, 2003; SEIDENBERG, 1997, etc.) defende a existência de apenas um léxico no qual todos os níveis de informação estão integrados. Recentemente, Elman (2009) apresentou uma nova e audaciosa proposta: a inexistência do léxico mental. Neste artigo, discutimos as diferentes perspectivas de estrutura e conteúdo do léxico mental com o propósito de questionar a arquitetura do conhecimento lexical no cérebro em contrapartida ao que pode ser conscientemente concebido como conhecimento lexical do falante. Procuramos dar continuidade à discussão proposta por Elman e confrontá-la com dados obtidos por estudos comportamentais, computacionais e de neuroimagem. Esta revisão teórica explica brevemente a evolução das concepções sobre o léxico mental desde a proposta da analogia ao dicionário até a proposta de sua inexistência. 
Palavras-chave: conhecimento linguístico; léxico mental; arquitetura em rede; processamento da linguagem; descrição da linguagem.

Recebido em 24 de março de 2014. Aprovado em 18 de novembro de 2014.

\section{Introduction}

This paper starts with a question "Does the mental lexicon exist?" To be able to address this question, it is necessary to establish what is meant by the word "lexicon". The Oxford Advanced Learner's Dictionary defines "lexicon" as (a) a list of words; b) a dictionary. There is no doubt that words exist and that they can be organized in lists, as can be seen in countless dictionaries available. To understand the nature of the mental lexicon it is also necessary to understand the cognitive nature of words. Saussure (1986) postulated the double dissociation of the sign: a signifier (the form) plus a signified (the meaning). The dual side coin metaphor, however, does not explain the complexity of meaning, therefore it is more plausible to associate a word with an irregular form like a diamond which has many faces representing many meanings. According to Vygostky (2001), the meaning of a word represents a close amalgam of thought and language. Words probably do not have static definitions in the brain; most of them are polyssemic and have literal and non-literal meanings that vary according to the context. Then, it seems more plausible to think as Elman (2004): words are clues to meanings.

Therefore, the lexicon is a core structure for language description and learning. When people start learning a language, one of the first steps is to learn a basic list of words. A similar step is taken by researchers; lexicon is a start point for language description. So, the existence of a lexicon that participates in all language processes, production and comprehension is a consensus. However, some disturbing questions come out when one tries to imagine how the knowledge of words that every language user has is stored and organized in the brain. Is the mental lexicon just a theory apparatus? Does it really exist in the brain? How is lexical information stored? Is it a dictionary-like structure? These may be mere speculations, but they constitute important issues for psycholinguistics research.

The beginning of Cognitive Sciences dates from the 1950s (TEIXEIRA, 1998) with the emergence of Artificial Intelligence and 
Computational Sciences that enabled new methods for understanding language processing. From the association of cognitive processes and computer processes, two paradigms were developed: symbolism and connectionism. The former tries to simulate the mind and the latter tries to simulate the brain. These two paradigms have produced many computational models of language processing. Presently, despite their limits, they strongly influence more advanced methods such as neuroimaging studies, which have been progressing especially from the 1990s.

The existence of a lexicon has been postulated by prominent researchers of language and cognition. According to Coltheart (2001), Ann Triesman in 1961 was the first to name a word store as a "mental dictionary'. However, "the human word-store" (AITCHISON, 1987) is much larger and complex than a dictionary and it has no fixed content. In face of these differences, Forster (1997) advises "whatever the limits of our understanding, we now know not to trust whatever intuitions we may have had on the basis of the dictionaries on our bookshelves", highlighting that a dictionary-like structure is too intuitive to be followed by researchers.

For some researchers the lexicon is a less important structure. Chomsky (1995, p. 235) claims it is "a list of 'exceptions', whatever does not follow from general principles", it is the source of languages variation. Fodor (1983, p. 80) suggests that "the mental lexicon is a sort of connected graph, with lexical items at the nodes and with paths from each item to several others"; it is a specialized computational mechanism inside the language module that contains only definitional information. More recently, in opposition to the new lexicalism, he argues that the lexicon is a label where people put things they do not know what to do with and they do not want to think about (FODOR, 2002, p. 75). Pinker $(1998$, p. 222) posits that "there is a lexicon of words for common or idiosyncratic entities; the psychological mechanism designed to handle it is simply a kind of memory"; working in association with the mental grammar (rules) to combine words. The same view is shared by Ullman et al. (2005, p. 185): "the lexicon contains memorized pairings of sound and meaning $[\ldots]$ non-compositional words and idioms, and it is governed by mental grammar rules". Jackendoff (2002, p. 130) assigns a more relevant role to the lexicon if compared to grammar, considering the mental lexicon as "the store of words in long-term memory from which the grammar constructs phrases and sentences", and where grammar information is stored. Therefore, in Jackendoff's view, grammatical information is embedded in lexical knowledge and do not constitute a hierarchical structure with grammar ruling over lexical items. 
For other researchers, the mental lexicon is a central structure. Formalists like Mel'cuk (2000, p. 1) asserts that "an ECD-type" lexicon must, and I think in the nearest future will, be one of the main components of any linguistic description". The lexicon is the core component of language and contains enriched linguistic knowledge. For connectionist such as Seidenberg and McClelland (1989, p. 560), "knowledge of words is embedded in a set of weights on connections between processing units encoding orthographic, phonological, and semantic properties of words, and the correlations between these properties."; it is embedded in a distributed network. Therefore, the mental lexicon is embedded in a distributed integrated network.

Despite arguing in favor of different views, researchers assume the existence of a kind of mental lexicon knowledge. In this paper, we explore different mental lexicon architectures, covering three approaches: the multiple lexicons view, the single lexicon view and the no-lexicon view. We start with an overview of the dissociation between multiple and single architectures and then we focus on the discussion of a new intriguing proposal, the existence of lexical knowledge without a mental lexicon. Would it be possible to propose language knowledge and processing without a lexicon? Would it be possible to explain language knowledge by an integrated language network able to store lexical (semantic and pragmatic) and grammatical knowledge in its nodes?

\section{Multiple lexicons view}

According to Coltheart (2001), one of the first models to pose a distinct store of words was Lichtheim (1885), whose model of spoken word processing was organized in three structures: a center for motor word representation, a center for auditory word representation and a concept structure. Presently, Coltheart (2001) identified similarities between Lichtheim's model and many other models, such as the ones proposed by Morton and Patterson (1980), Harris and Coltheart (1986),

\footnotetext{
${ }^{1}$ ECD - Explanatory Combinatorial Dictionary. Despite the Meaning-Text Model be uniquely a linguistic description attempt, without an explicit association with cognition and the mental structure of lexical knowledge, we mention it because of the importance that the lexicon has in Mel'cuk (2000) model.
} 
Ellis and Young (1988), and Kay, Lesser and Coltheart (1992). They postulate distinct cognitive modules for language processing: a) a store of concepts; $b$ ) a store of sound pictures - or auditory input - representation; c) a store of spoken words - output- representation; d) a store of object representations. Separate stores for distinct information levels.

The multiple lexicons view also has its origins in a more general theory of domain specific faculties in the brain (Franz Joseph Gall 17581828). More recently, the modularity theory has been modified by Fodor (1983). He postulates the existence of two systems in the mind: input system and central system. The former constitutes a family of six functionally distinct modules: hearing, sight, touch, taste, smell and language; within them there are highly specialized computational mechanisms. The input systems are domain specific, mandatory, informational encapsulated, neurologically hardwired and innately specified; their main function is input analysis. Central systems are less known and explored by science. They have the function of fixation of beliefs. They are not domain specific neither encapsulated; they concern more general mental processes that are not local as analogical reasoning. Fodor (1983) is concerned about psychological faculties, among them language, which is one of the input systems and shares all the listed characteristics with them.

The idea of distinct modules that perform local processes composed by specialized computation mechanism is surely present in the multiple lexicons view. Beyond this view, researcher's detachment criteria vary on: semantic $v s$. lexical, orthographic $v s$. phonological, lexical vs. grammatical, L1 vs. L2.

Aphasic research provides evidence for the existence of "different lexicons, according to the kind of information they store: semantic information would be stored in a set of brain regions, syntactic information in another place and phonological in a third set" (LENT, 2001, p.627). The same author lists, from Wernicke's model updated, the following locations:

- Semantic lexicon: middle and inferior temporal gyrus, where the anterior pole is responsible for identifying people's names, and the posterior pole for animals and objects.

- Syntactic lexicon: frontal cortex anterior to Broca's area.

- Phonological lexicon - Wernicke's area.

Hillis (2001) postulates the existence of distinct lexicons for auditory and written information. She presents a schematic representation 
of the organization of the lexical system based on evidence from aphasic patients. This representation has two lexicons: one phonological and one orthographic; they are subdivided into input and output according to their functions. As a result of this proposal, literacy involves the creation of a new store of lexical information, a visual store named orthographic lexicon.

Following the same path, Teichmann and colleagues (2012) present evidence for lexical and semantic distinction. They present a case report about a patient with semantic dementia: the patient could not define very common words but she could resolve anagrams with the same performance of healthy people even without knowing their meanings. According to the authors, "lexicon and word semantics are 2 distinct functional and presumably anatomic entities" (Ibid., p. 2); the orthographic lexicon is stored in inferior temporal cortices in an area named the visual word form area, while semantic information is stored in the anterior temporal cortices. This case study corroborates the multiple view underpinning an autonomous mental lexicon and a dissociated semantic store.

Ullman (2007, p. 268) situates the mental lexicon "on temporal lobes, mainly but not exclusively in the left hemisphere", where phonological processing occurs in mid-to-posterior superior temporal cortex and conceptual information in front and below phonological region. Ullman and colleagues (1997) advocate that language processing is dependent on more general cognitive networks, so that there is a correspondence between the mental grammar and the procedural memory (frontal / basal ganglia), and between the mental lexicon and the declarative memory (temporal-parietal / medial-temporal). Data from studies on Alzheimer, Parkinson and Huntington's disease patients point to dissociation between grammar and lexical-semantic functions in the brain. The two systems interact in many ways (ULLMAN, 2004): damage in one system can lead to improvement on learning and processing of the other; some types of knowledge can be acquired by both systems; a knowledge that firstly was declarative can become automatized on procedural memory. This proposal contributes to unify research on mind and brain because it tries to correlate structures postulated in mental models with brain functions and areas.

Lexical and grammatical dissociation is also present in Sahin and colleagues's work (2009). They investigated linguistic processing in Broca's area using intracranial electrophysiology (ICE). Their aim was to find out whether there is distinct time and space in lexical, grammatical and phonological processes. The experiment design has three different conditions: 
a) Read: only read and repeat sentences followed by a word (verb or noun), no change required; b) Null-Inflect: read a sentence (e.g. every day they) and then read a verb or noun (e.g. to walk), requires inflection; c) Overt-Inflect: read a sentence (e.g. yesterday they) followed by an infinitive verb (e.g. to walk), require inflection and change in phonology.

The results showed a three step serial process: a) 200ms lexical information (word identity) sensitive to word frequency and subsequent to primary lexical access in the temporal lobe; b) $\sim 320$ inflectional processing (grammatical endings) channel A3-4 of area 45 ; c) $\sim 450$ phonological processing (word sounds) channel A4-5 of area 45. The authors conclude that there is a "spatiotemporally distinct process" of lexical, grammatical and phonological information.

Hagoort and Levelt (2009) found in Sahin and colleagues' investigation, mentioned above, confirmation for their theory of lexical access (LEVELT, 2001) represented in the following picture.

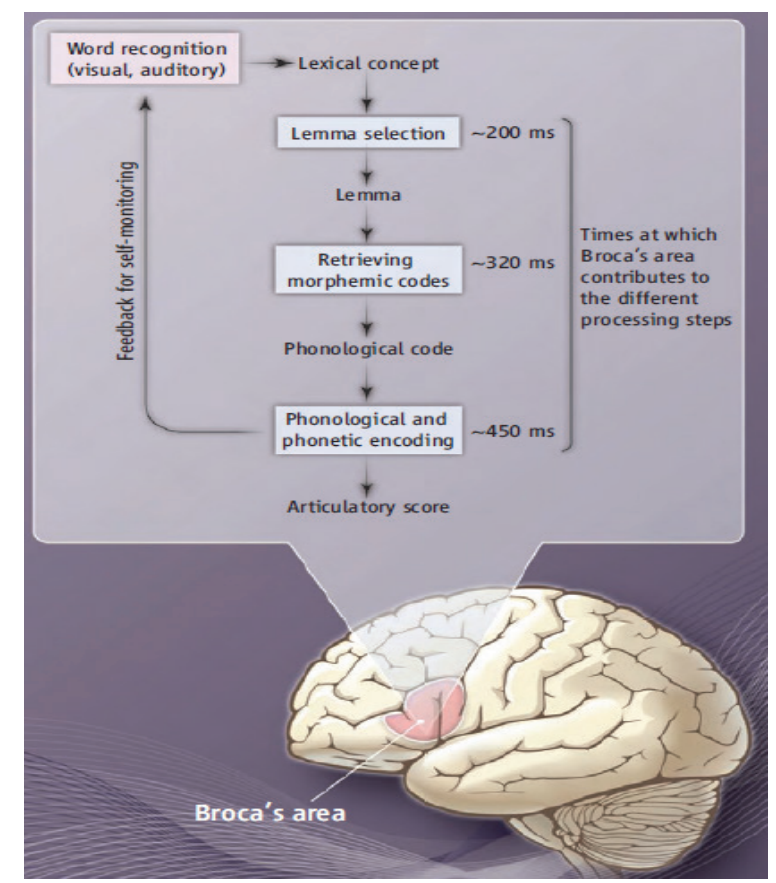

Figure 1 - Adapted version of the lexical encoding model for speech production specifying stepwise neuronal processing of language and speech. 
The theory postulates a serial two-system architecture for language production. The first system is responsible for lexical selection, which occurs in two steps: conceptual focusing / perspective taking that accesses lexical concept, and lemma selection that accesses syntactic information. The second system receives information from lemma selection and proceeds form encoding. It occurs in three steps: retrieving morphemic phonological codes, prosodification syllabification, and phonetic encoding. The model posits the existence of a "mental syllabary" and has been implemented in a computational model WEAVER++. Levelt's model is a classical example of a multiple and serial view of lexical processing.

The multiple lexicon view is also found in bilingualism studies. They address the question of how multiple languages are stored, either in a unique lexicon or in many lexicons, one for each language. Singleton (2007, p. 13) agrees that there is a strong cross-lexical connectivity between the lexicons; however, he argues that there is no evidence to support the "notion of a complete absence of differentiation". He mentions four main arguments in favor of a separation: a) modularity hypothesis; b) language different formal terms; c) selective recovery of languages lost in brain damage episodes; d) contrastive analysis hypothesis; e) other circumstances of language lost. Singleton makes a brief review of seven studies that support the view of partial but not total integration.

On a review of bilingual models, Heredia (2008) also confirms the predominance of the multiple view. Hierarchical models propose one conceptual level and two lexicons, and on the revised version the two lexicons are interconnected bi-directionally via lexical links. The distributed conceptual feature model also distinguishes the lexicons and postulates that the words in the two lexicons can share more or less semantic features - the more they share, the more similar their concepts will be. The bilingual interactive model, a connectionist model, assumes two lexicons too. All bilingual models referred in her work, despite their differences, postulate the view of multiple lexicons for different languages.

In this brief review, it is evident that the multiple lexicons view is strong and supported by a tradition of theoretical models and by different sources of investigation. Postulating different lexicons for different linguistic information might be a simple solution for language models. 
However, it is questioned by researchers that argue in favor of a more integrated architecture, more consonant with the brain connectivity. The next section will present new elements to the discussion.

\section{The single lexicon view}

The single lexicon view is influenced by connectionists' models that postulate unified processes. Connectionist models try to simulate the activity of the smallest processing units of the brain, the neurons, and the weight of the connections among them, the synapses. They are "computational models often used to model aspects of human perception, cognition, and behavior, the learning processes underlying such behavior, and the storage and retrieval of information from memory" (MCCLELLAND; CLEEREMANS, 2009, p.177). The main characteristics of these models are network connectivity and parallel processing. Knowledge is not stored in modules, but it is distributed in the neural networks. Neuron-like units are distributed in hierarchical layers: input, hidden and output layers. There are no fixed previous rules, but a learning algorithm capable of adjusting the strength of connectivity ('synapses') between the units ('neurons') through learning experience. According to Söhngen (2004, p. 224), distinct brain regions are not responsible for complex mental faculties, as proposed by modularists, but they make complementary operations.

Concerning the mental lexicon, some connectionist models postulate the existence of only one lexicon and some other postulate the inexistence of a lexicon, this is the "no-lexicon view" to be presented in the next section. This difference comes from the network architecture. When simulating a process as speaking and reading one needs to have a previous theory to guide the design of layers and their function. So you can build complex models with many unit layers or simple models with just three layers and a single route process.

One of the most influential connectionist models was proposed by McClelland and Rumelhart (1981). The Interactive Activation Model of context effects in letter perception is organized into six interactive levels: a higher level (top-down input - conceptually driven), a word level, a letter level and a feature level, a phoneme level and an acoustic feature level (see FIGURE 2). The word level is the lexicon of the system; it has 1.179 four-letter words. The process is parallel, then it occurs 
simultaneously in several levels; it is also interactive, so that top-down processing occurs in conjunction with bottom-up ones. "Communication proceeds through a spreading activation mechanism in which activation at one level spreads to neighboring levels." (Ibid., p. 378). Input is processed through excitatory and inhibitory messages sent by the levels. In the word level, the units are mutually inhibitory, so that they compete with each other. Although not considering the higher level, phonological processing and reciprocal activity for simulations, the model shows robustness and accounts for the results on letter perception in words and nonwords (pseudowords) reported in the literature.

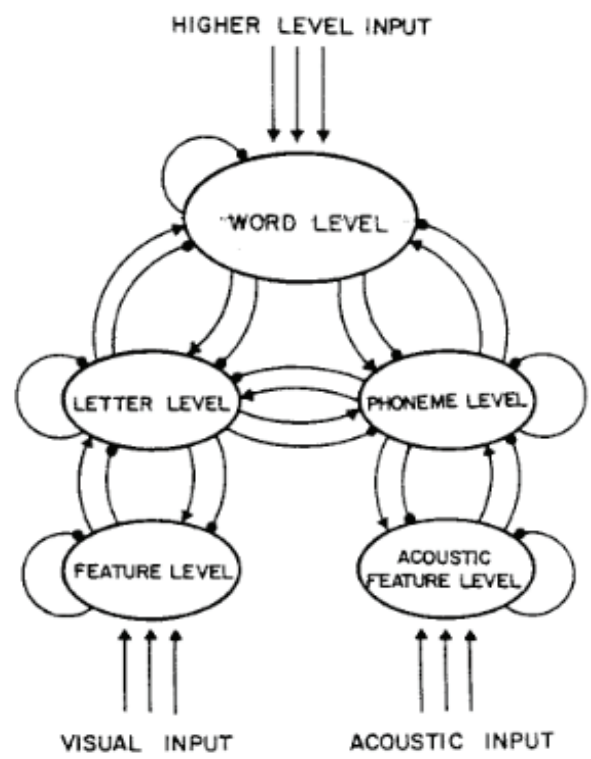

Figure 2 - The Interactive Activation Model.

Source: McClelland and Rumelhart (1981, p. 378).

A similar model was created to speech perception: TRACE (MCCLELLAND, ELMAN, 1986) is also an interactive activation model, meaning that "information processing takes place through the excitatory and inhibitory interactions among a large number of processing elements called units" (Ibid., p. 2). Activation spreads through three unit levels: features (ex: voiced, nasal), phonemes and lexical entries, that mutually 
influence each other. Each level has its own detectors. Regarding the lexicon "there is a unit for every word in every time slice. Each of these units represents a different hypothesis about a word identity and starting location." (Ibid., p.18). TRACE II ${ }^{2}$ has 211 words stored. Their representation is phonological, there is no semantic representation, as the model's aim is to simulate perception. Norris (1994) reformulated TRACE and created the Shortlist Model, whose main difference is a bottom-up architecture and two-stage processing (lexical search and constraint satisfaction). It also has a lexicon where lexical search occurs. Despite its larger vocabulary word recognition, Shortlist Model just accounts for word recognition, not for phoneme recognition as TRACE, and fits more into modular models.

Caramazza (1996), based on neuroimaging studies of Damasio et al. (1996), proposes the existence of a lexical representation, abstract and modality independent, that mediates phonological and conceptual representation. The lexical level is organized into semantic categories in the left temporal lobe. Figure 3 illustrates the model.

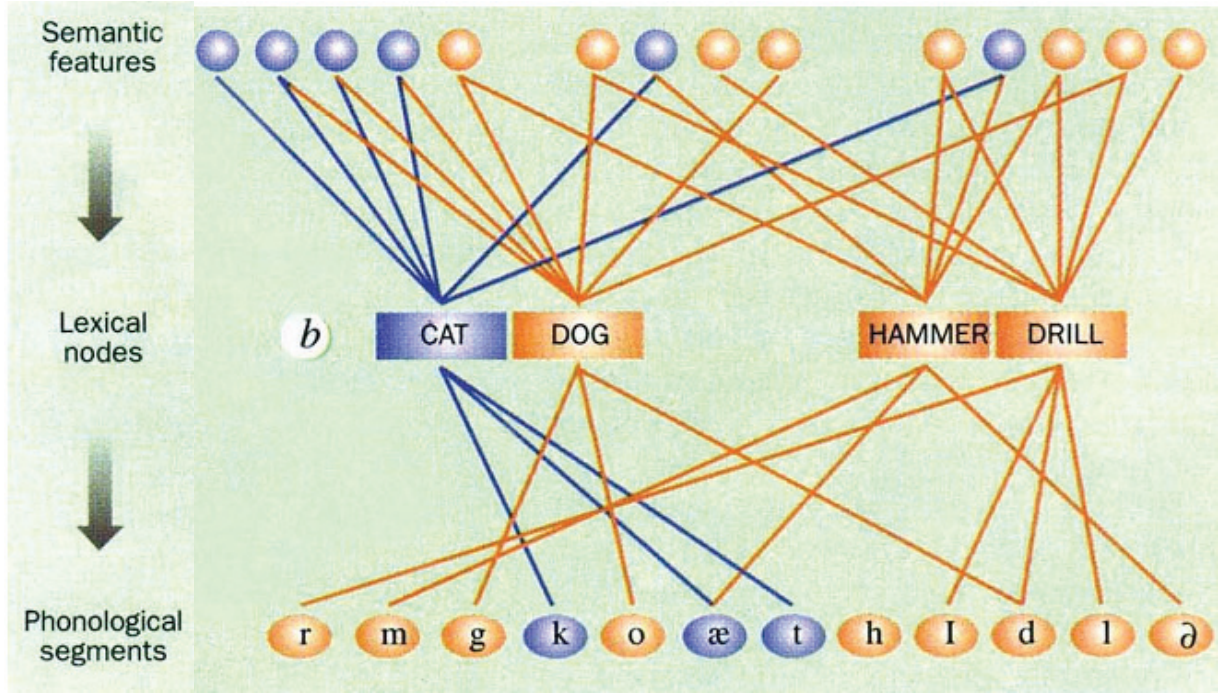

Figure 3 - Speech production model.

Source: Caramazza (1996, p. 485).

${ }^{2}$ TRACE I is for computation and TRACE II is for psychological modeling. 
In this proposal, the mental lexicon seems not to hold phonological nor semantic knowledge, but it mediates and integrates the two levels. It is not clear if the word level is similar to the lemma level, where syntactic information would be represented. He claims that "the part of word knowledge that is organized categorically in the left temporal lobe is the lexical level and not the conceptual or phonological levels" (Ibid., 1996, p. 485). Lexicon here seems to be an interface level that connects semantic and phonological segments. On the contrary, in the model's reformulation, Caramazza (1997) clearly excludes the lemma level and denies the existence of any interface, so that semantic nodes are directly linked to orthographic lexemes, syntactic features and phonological lexemes.

An interesting model developed by Dell, Chang and Griffin (1999) is the Aphasia Model which tries to explain error patterns aphasic and nonaphasic speakers make in picture naming experiments. Its architecture is made of three layers: semantic features, words and phonemes. The layers are linked by bidirectional excitatory connections that interactively activate each other. It is different from the previous model because it has two steps of retrieval: lemma selection and phonological encoding. To simulate aphasic errors, the system is lesioned by reducing activation transmission and maintenance between layers. Despite its limits, the model has excellent results. It accounts for normal and aphasic performance on picture naming tasks confirming the authors' hypothesis that "brain damage entails disruption in the ability to transmit and maintain activation.” (Ibid., p. 524). Aphasia research usually points to separate stores of knowledge, since patients exhibit different kinds of errors; this model, however, explains errors in a very simple way, challenging the multiple lexicons view.

Other relevant single view model was designed by Burke and Shafto (2004) to explain the tip-of-the-tongue (TOT) phenomenon especially in older adults. The Transition Deficit Model has three wide systems organized into interactive information nodes: a) semantic propositional nodes and lexical nodes; b) phonological - syllable nodes and phonological nodes; c) orthographic - irregular nodes and orthographic nodes. According to the authors, "TOTs occur when semantic and lexical representations corresponding to a word are activated, causing a strong feeling of knowing the word, but activation of phonological information about the word is incomplete." (2004, p. 22). They explain that the failure 
occurs because phonological representations become weak particularly in elderly speakers. Other cause of weaken connectivity is recency and frequency of word's activation. The model also explains spelling errors associated with phonology, this was the reason to include an orthographic system. Older adults tend to maintain and improve semantic knowledge; however, they have increasing problems with form retrieval. The model explains a phonological activation deficit. The main point in this model is the position of lexical representation; it is not an independent system as in other models; it is inside the semantic system. This seems to be an intermediate position between the single lexicon view and the no-lexicon view exposed in the next section.

The single lexicon view has a variety of models that can explain and some actually simulate the human linguistic behavior challenging modular theories. However, besides its gain in interactivity and parsimony, it also faces problems like the uncertainty about words representation. Assuming the existence of a word level raises questions like: what information is represented in the lexicon and how? The single view models were the precursors of the no-lexicon view, as can be seen in the next section.

\section{The no-lexicon view}

Some connectionists go further and propose linguistic models without a mental lexicon, where all information levels (semantic, syntactic, phonological, orthographic, sensorial, pragmatic, etc.) are integrated and interconnected in the same network. The no-lexicon view is not actually new, it has been discussed by connectionists for many years, but it seems to be reinforced since Elman's proposal (2004). One may say it is just a matter of architecture, but simple recurrent networks (SRN) produce impressive results. They do not draw a distinction between semantic and lexical memory and can perform linguistic tasks as reading (SEIDENBERG; MCCLELLAND, 1989), lexical decision (BULLINARIA, 1995) and prediction (ELMAN, 1990). These results raise questions like: if a simple network can have human like performance on language tasks without a lexicon, does the mental lexicon really exist? The interdependence of semantic memory and lexical memory (phonological and orthographic labels) is a challenging question to psycholinguists. 
A very influential model that drives this view is the Distributed Developmental Model of Word Recognition and Naming (SEIDENBERG; MCCLELLAND, 1989). It is a very robust model with four main representational units: orthography, phonology, meaning and context, plus three hidden units that mediate the others. Its main precursor is the Interactive Activation Model of Word Perception (MCCLELLAND; RUMELHART, 1981), briefly described in the previous section. Its primary difference is the exclusion of feature levels and word level (lexicon). The model assumes reading as the computation of three types of codes: orthographic, phonological and semantic codes. These codes have distributed representation and their representation building is interactive since the three levels influence each other. The model was implemented in a simplified version (just three units: orthographic, hidden and phonological) and focused on learning processes. Beyond the important results of its simulations is the model's effectiveness on lexical decision without lexical access. The authors explain that "lexical memory does not consist of entries for individual words" and "knowledge of words is embedded in a set of weights on connections between processing units encoding orthographic, phonological, and semantic properties of words, and the correlations between these properties." (MCCLELLAND; ST. JOHN; TARABAN, 1989, p. 560). Lexical representation is not stored in one or multiple lexicons. It is distributed in a network; therefore there is no lexical access, no lexical retrieval and no lexical integration. There is the activation of different levels of information in a network.

An important characteristic of the no-lexicon view is the inseparability of lexicon and grammar. Bates and Goodman (1997) make an extensive review of investigations into language acquisition of normal and atypical population, neurological disorders among older children and adults, and also online processing studies. They claim that there is no consistent evidence for a modular independent process of grammar and lexicon. Based on Elman $(1990,1993)$ and many other reviewed researches, they suggest that "grammar knowledge may take a much less explicit form, emerging from the process by which words and morphemes are activated in time." (BATES; GOODMAN, 1997, p. 565). According to this view, all linguistic information is contained in a complex and integrated network and it is distributed in a high-dimensional space with different linguistic levels, but that are not stratified nor encapsulated in nature. 
The no-lexicon view has its origins at Seidenberg and McClelland (1989), McClelland and colleagues (1989), followed by Elman (1990, 1993) and it clearly grows in Elman's papers published in 2004 and 2009 when he finally proposes the inexistence of a mental lexicon. As Bates and Goodman (1997) explain, changes in generative theory (CHOMSKY, 1995) weakened grammar emphasis, while the appearance of publications as Lexical Functional Grammar (BRESNAN, 2001) and Usage-based theory (TOMASELLO, 1992) makes the trend through lexicalism to return to linguistics. So that not just connectionist models, but other psycholinguistic theories start admitting lexicon as an integration structure of all linguistic information levels. This theoretical change collaborates to Elman's proposal acceptance and growth.

Elman (2004) proposes "an alternative view of mental lexicon" based on Hebb's (1949) assumptions and on simple recurrent networks. He suggests to "[...] treat words as stimuli, whose 'meaning' lies in the causal effects they have on mental states." (Ibid., p. 306). Words work as clues (stimuli) to activate a pool of nodes and connections that can be described as a word meaning in a discourse context, words' categories are emergent from the location in a high-dimensional state space. They work "as 'operator' rather than as 'operand"" (Ibid., p. 301). Therefore the mental lexicon is not a passive word store as a long list of information. It is in fact a great dynamic network where senses are distributed and sensitive to context. The meaning of a word group depends a lot on the meanings of the constituent words, therefore sense and meaning are context depended.

Elman (2004) illustrates his ideas exemplifying how a simple recurrent network can learn to predict words. In this simulation experiment implemented by Elman (1990), words receive a code of 0s and a single 1 and have no linguistic information. The network's architecture is formed by four units: input, hidden, output and context. After training sentences, the network is able to predict the next word. The hidden unit evokes patterns that reflect the word's category membership in response to each word. As shown in Figure 4, the network is capable of organizing words in groups of nouns (animate - animals, humans; inanimate - food, breakables) and verbs (intransitive, transitive - always and sometimes). 


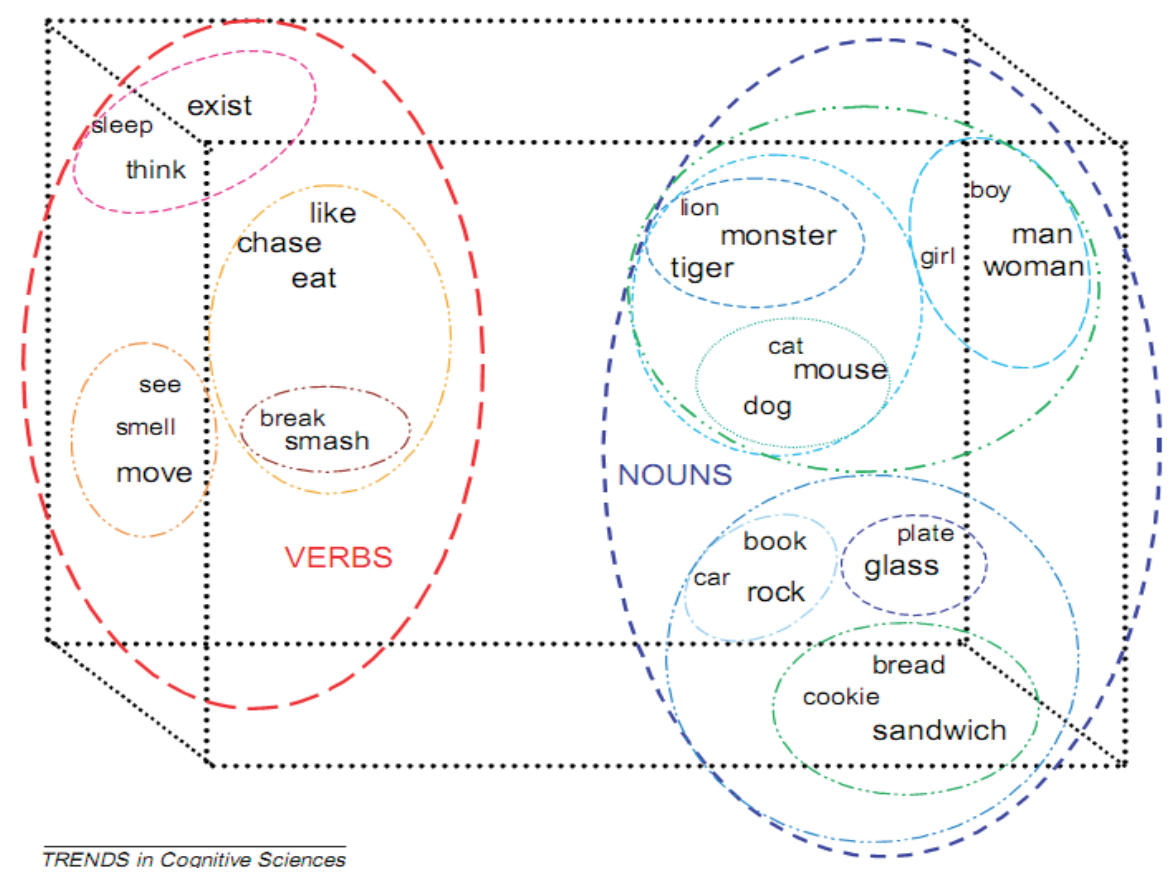

Figure 4 - Schematic visualization, in 3D, of the high-dimensional state space described by the SRN's hidden-unit layer.

Source: Elman (2004, p. 304).

What is impressive is that each occurrence of the same word produces a similar but not an identical space. "The actual words that one processes in any given utterance are 'tokens' of that type" (ELMAN, 2004 , p. 303). For example, 'boy' is a token of human type, 'bread' is a token of food type. The state is produced in the same bounded region, but it is different because it is loaded of information from prior context experience. In sum, the network, without any previous linguistic information or rule, is capable of producing syntactic distinction, nouns and verbs, semantic distinction and combination, word categories and word groups, and learns how to make word predictions in a sentence. Therefore lexicon and grammar emerge as a result of learning.

In 2009, Elman finally proposes "to do away with one of the objects most cherished by language researchers: the mental lexicon. I 
do not call into question the existence of words, nor the many things language users know about them. Rather, I suggest the possibility of lexical knowledge without a lexicon" $(2009$, p. 2). This view is supported by a considerable amount of research that suggests increasingly richer and more detailed lexical representations, in which lexical, syntactic and event knowledge are strongly integrated and context driven. ${ }^{3}$ As limits between information levels and linguistic and non-linguistic aspects become unclear, the quantity of information supposedly retained in the mental lexicon is amplified. It takes us to an impasse: after all, how could the lexicon contain representation of all levels of information being it linguistic or non-linguistic?

Elman's solution is the exclusion of the mental lexicon as the traditional structure usually postulated by theories. Lexical representation in his view is integrated to the other linguistic levels (syntactic, semantic, phonologic, pragmatic, etc.). Language is a dynamic system which does not follow previously established rules; on the other hand, rules can be useful to describe a language system. According to Elman (2009, p. 2), words should be treated "not simply as flesh that gives life to grammatical structures, but as bones that are themselves grammatical rich entities". Words work as external stimuli that affect the system's internal state as a function of the network's prior state (memory) and the network's dynamical structure (grammar) encoded in its weights. In brief, grammar is determined by use and word meanings too, supporting an account of context dependent meaning. What is behind this view is a very basic principle of connectionism: statistic generation - frequency and stimuli sensitivity. The author argues that his alternative view, where all information is unified and interacts, is more suitable to account for language dynamism, especially because it can explain words' meaning ambiguity and context dependency.

Hebb's postulates ${ }^{4}$ are also revisited by Pulvermüller (1999). In his perspective, knowledge is not represented in small areas in the

\footnotetext{
${ }^{3}$ Verbs are a good example; a verb entry should contain subentries for each sense, subcategories frames and their probabilities for each sense, and argument / thematic role for each sense.

4"The entire cortex is an associative memory" (PULLVERMÜLLER, 1999, p. 254) and association occurs between coactivated neurons that can be adjacent or distant; these associated neurons develop a functional unit (cell assembly).
} 
brain nor it is entirely distributed. Knowledge is represented by cell assemblies that have a specific function and topography, but are not necessarily closely situated. Pullvermüller (1999) proposes a prominent improvement: "connection strength is not only modified by coincident activity, it also changes if only one of two connected neurons is active while the other one is inactive." (Ibid., p. 255) He calls this new principle 'correlational learning'; its main advantages are frequency information store and strength of correlated activations, important characteristics of connectionist models.

Regarding words, Pullvermüller (1999) explains that their representation is bilaterally distributed in an interconnected network of cell groups with a well defined cortical topography. He claims that a brain representation is a picture of cell groups whose activity is simultaneously activated the moment it was acquired. Figure 5 shows two interconnected networks, one for form, left lateralized, and one for meaning, bilaterally distributed. Motor (articulatory) and acoustic representation of words occurs in the perisylvian cortices where Broca and Wernicke are localized. This is a strongly connected network that works as a distributed functional unit of phonological and grammatical features. This network also connects bilaterally to others where different sense features (meaning) are represented. For example: the motor cortex is activated to process verbs that involve body movement; the visual cortex participates in concrete nouns representation as animals and colors; the limbic system is activated when processing features of words that express feelings and emotions.
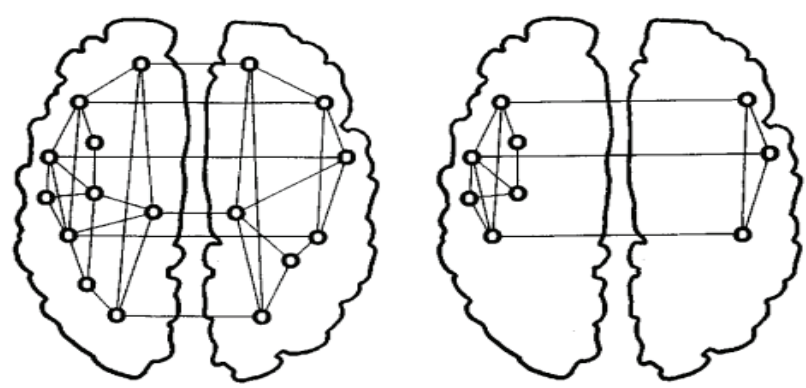

Figure 5 - Cell assemblies relevant for cognitive processing may be distributed over both hemispheres and may be lateralized to different degrees.

Source: Pullvermüller (1999, p. 261). 
In Pullvermüller, we find a biological explanation to Elman's view. If "neurons related to a word form become active together with neurons related to perceptions and actions reflecting aspects of its meaning." (1999, p. 260), so there is no space for a fixed structure as a mental lexicon. It also corroborates the understanding of usage-based knowledge, as word learning is a matter of correlational activation between neuron networks that store form and meaning. Cell assemblies are compared to dynamical systems as Fuster (1999) explains: "cortical distribution of a word is tied to the idiosyncratic distribution of associated memories", therefore word meanings vary according to the learner's experience.

Evidence in favor of the no-lexicon view also comes from research with people who suffer from semantic dementia (DILKINA et al., 2008), due to an atrophy in the anterior temporal cortex. They show conceptual knowledge deficits associated to lexical deficits. Variability on this correlation was explained in a simulation made by Dilkina, McClelland and Plaut in 2010. They built a connectionist model with an integrative layer (semantic - functionally analogous to the anterior temporal cortex) and a hidden layer (phonology and orthography representation - functionally analogous to the left posterior superior temporal / angular region). The model was trained and had $100 \%$ of accuracy on lexical decision tasks. After damaged at semantics, the model's performance was similar to semantic dementia patients. Lexical decision on less consistent spelling words diminished and was strongly correlated with the accuracy on semantic tasks. The correlation observed between lexical and semantic tasks was overall, not item-by-item. This happens because in a connectionist network each level is sensitive to the activity on other levels as they are connected by an integrative layer. They conclude that "lexicons are not necessary for lexical decision." (DILKINA et al., 2008, p. 75) what corroborates the no-lexicon view. Therefore, lexical and semantic processes are dependent on a single integrated network governed by two orthogonal dimensions: spelling consistency (phonology-orthography mapping) and concept consistency (visual and action / encyclopedic mapping).

The no-lexicon view is consistent with language distribution in the brain. There is possibly not a place for lexicon and another for grammar, words are not represented individually with their definitions. Brain's anatomy seems to be more consistent with a wide distributed 
network where all linguistic levels are integrated. In addition to that, these connectionist models are coherent to Saussure's idea about words, their two dimensions meaning and form are represented in the models as phonology layer and semantic layer. Mapping between them is a process, since there is not a structure to store the list of mappings. In a lexical decision task, for example, instead of accessing the mapping, the mapping is being done ad hoc. It is not ready, it has to be done, improved, reinforced and automatized by experience.

\section{Conclusion}

Researchers still do not know the brain enough to unfold the mysteries of the mental lexicon. The existence of a mental lexicon, its structure and functioning is still very dependent on theories about language and cognition. Most neuroimaging studies seem to adopt a multiple lexicons view and keep on trying to find a place for the mental lexicon(s).

However, if we assume the lexicon to contain all linguistic information, then it is necessary to account for a wide distributed network in the brain: the classic Broca and Wernick areas, visual form area (DEHAENE, 2012) for written language, right hemisphere regions for coarse semantic coding (BEEMAN; CHIARELLO, 1998), discourse processing (SCHERER, 2009; MASON; JUST 2006) and pragmatics (SCHMIDT; SEGER, 2009; SAXE, 2006; BAMBINI, 2010), etc. Looking from this point of view, the mental lexicon seems to be more a theory apparatus created to explain language processing, rather than a real structure.

The mental lexicon has joined so much information that like a star of extreme density it seems to implode and tumble down itself (ELMAN, 2009). Its structure could not support its weight and would implode. If the mental lexicon gathers so many levels of distinct information, it might be the integration itself and not the storage. Words are units; they contain phonological, orthographical, semantic, syntactic and pragmatic information. Words seem to be the language's processing units and the mental lexicon, in turn, the integrator of all these information levels.

A similar view is presented by Gow (2012) based on the dual pathway organization of Wernicke's model (HICKOK; POEPPEL, 2007). He claims that all lexicon models share an essential property: "word is a 
kind of interface that links representations of word form or sound with other types of knowledge" (GOW, 2012, p. 277). Therefore, the mental lexicon would be responsible for integrative operations, like hidden nodes in connectionist models. Based on this view, Gow suggests the existence of two integrative parallel structures in the brain: the ventral lexicon (posterior temporal lobe) for sound-meaning mapping - it integrates acoustic phonological representation in bilateral superior temporal gyrus to bilaterally distributed semantic representations; and the dorsal lexicon (inferior parietal lobe) for sound-articulation mapping - it links acousticphonetic structure to left frontal regions responsible for articulation.

Gow (2012) reviews BOLD imaging studies and pathologies that confirm the existence of two integrative structures; however, there is no consensus about the relation between the lexicon and the inferior parietal lobe. Hickok and Poeppel (2007)'s study, for example, attributes different denominations: 'sensorimotor interface' (dorsal lexicon) and 'lexical interface' (ventral lexicon), being the 'lexical interface' more similar to a mental lexicon as a phonological and semantic integrator. The different denominations emerge from theoretical conceptualizations, since Gow defines lexicon as an interface structure, linking comprehension and production. The existence of separate input and output lexicons is an issue that has been discussed within computational models for a long time and it certainly needs more research.

Along this brief review, the mental lexicon has shown different meanings for different research groups. It has not been localized probably because there is no consensus about its function (GOW, 2012). In face of these considerations, an important step for future research is certainly defining the lexicon's function, if it is a storage structure or an interface structure. For the moment, a plausible solution to Elman's impasse would be to accept the lexicon as an interface structure that does not store all linguistic and non-linguistic information, but integrates information widely distributed in the brain. Although we can consciously think about our lexical knowledge - and it is a powerful strategy in improving it (SOUSA; GABRIEL, 2011) this knowledge might be distributed in a complex network where pieces of linguistic and nonlinguistic information are stored and patterns of activation make some routes easier than others due to different variables, among them frequency of use, for example. 


\section{References}

AITCHISON, J. Words in the mind: an introduction to mental lexicon. Oxford, Basil Blackwell, 1987. 326 p.

BAMBINI, V. Neuropragmatics: a foreword. Italian Journal of Linguistics, v. 22, n. 1, p. 1-20, 2010.

BATES, E.; GOODMAN, J. C. On the inseparability of grammar and the lexicon: evidence from acquisition, aphasia and real-time processing. Language and cognitive processes, v. 12, p. 507-584, 1997.

BEEMAN, M.; CHIARELLO, C. (Ed.). Right hemisphere language comprehension: perspective from cognitive science. New Jersey: LEA, 1998. 424 p.

BRESNAN, J. Lexical-Functional Syntax. Oxford: Blackwell Publishers, 2001. 446 p.

BULLINARIA, J. A. Modelling Lexical Decision: who needs a lexicon? In: KEATING, J. G. (Ed.). Neural Computing Research and Applications III. Maynooth, Ireland: St. Patrick's College, 1995, p. 62-69.

BURKE, D. M; SHAFTO, M. A. Aging and Language Production. Current Directions in Psychological Science, v. 13, n. 1, p. 21-24, 2004. CARAMAZZA, A. How Many levels of processing are there in lexical access? Cognitive Neuropsychology, v. 14 (1), p. 177-208, 1997.

CARAMAZZA, A. The brain's dictionary. Nature, v. 380, p. 485-486, 1996.

CHOMSKY, N. The minimalist program. Cambridge, MA: MIT Press, $1995.420 \mathrm{p}$.

COLTHEART, M. R. K.; PERRY, C.; LANGDON, R.; ZIEGLER, J. DRC: a dual route cascaded model of visual word recognition and reading aloud. Psychological Review, v. 108, n. 1, p. 204-256, 2001.

DAMASIO, H.; GRABOWSKI, T. J.; TRANEL, D.; FRANK, R. J.; HICHWA, R. D.; DAMASIO, A. R. A neural basis for lexical retrieval. Nature, v. 380, p. 499-505, 1996.

DEHAENE, S. Os neurônios da leitura: como a ciência explica a nossa capacidade de ler. Porto Alegre: Penso, 2012. 374 p.

DELL, G. S.; CHANG, F.; GRIFFIN, Z. M. Connectionist models of language production: lexical access and grammatical encoding. Cognitive Science, v. 23, n. 4, p. 517-542, 1999. 
DILKINA, K.; MCCLELLAND, J. L.; PLAUT, D. C. Are there mental lexicons? The role of semantics in lexical decision. Brain Research, v. 1365, p. 66-81, 2010.

DILKINA, K.; MCCLELLAND, J. L.; PLAUT, D. C. A single-system account of semantic and lexical deficits in five semantic dementia patients. Cognitive Neuropsychology, v. 25, p. 136-164, 2008.

ELLIS, A. W.; YOUNG, A. Human cognitive neuropsychology: a textbook with readings. London: Erlbaum, 1988. 695 p.

ELMAN, J. L. On the meaning of words and dinosaur bones: lexical knowledge without a lexicon. Cognitive Science, v. 33, p. 1-36, 2009.

ELMAN, J. L. An alternative view of the mental lexicon. Trends in Cognitive Sciences, v. 8, n. 7, p. 301-306, 2004.

ELMAN, J. L. Learning and development in neural networks: the importance of starting small. Cognition, v. 48, p. 71-99, 1993.

ELMAN, J. L. Finding Structure in Time. Cognitive Science, v. 14, p. 179-211, 1990.

FODOR, J. A. The lexicon and the laundromat. In: MERLO, P.; STEVENSON, S. (Ed.). The lexical basis of sentence processing. Amsterdam: John Benjamins, 2002, p. 75-94.

FODOR, J. A. The modularity of mind: an essay on faculty psychology. MIT Press, Cambridge, MA, 1983. 145 p.

FORSTER, K. I.: Words, and how we (eventually) find them Accessing the mental representation of words. In: ALTMANN, G. The ascent of Babel: an exploration of language, mind, and understanding. Oxford University Press, 1997, p. 65-83.

FUSTER, J. M. Hebb's other postulate at work on words. Behavioral and Brain Sciences, v. 22, p. 288-289, 1999.

GOW, D. W. J. The cortical organization of lexical knowledge: a dual lexicon model of spoken language processing. Brain \& Language, v. 121, p. 273-288, 2012.

HAGOORT, P.; LEVELT, W. J. M. The Speaking Brain. Science, v. 326, p. 372-373, 2009.

HARRIS, M.; COLTHEART, M. Language processing in children and adults: an introduction. London: Routledge and Kegan Paul, 1986. 274 p. 
HEBB, D. O. The organization of behavior. New York: Wiley: 1949. 335 p. HEREDIA, R. R. Mental models of bilingual memory. In: ALTARRIBA, J. A.; HEREDIA, R. R. An introduction to bilingualism: principles and processes. New York: Erlbaum, 2008, p. 39-67.

HICKOK, G.; POEPPEL, D. The cortical organization of speech processing. Nature Reviews Neuroscience, v. 8, n. 5, p. 393-402, 2007.

HILLIS, A. E. The organization of the lexical system. In: RAPP, B. (Ed.). The Handbook of Cognitive Neuropsychology: what deficits reveal about the human mind. Philadelphia: Psychology Press, 2001. p. 185-210.

JACKENDOFF, R. Foundations of language: brain, meaning, grammar, evolution. New York, Oxford University Press, 2002. 477 p.

KAY, J.; LESSER, R.; COLTHEART, M. PALPA: Psycholinguistic assessments of language processing in aphasia. Hove, England: Erlbaum, $1992.650 \mathrm{p}$.

LENT, R. Cem bilhões de neurônios: conceitos fundamentais de neurociência. São Paulo: Atheneu, 2001. 698 p.

LEVELT, W. J. M. Spoken word production: a theory of lexical access. $P N A S$, v. 98, n. 23, p. 13464-13471, 2001.

MASON, R. A.; JUST, M. A. Neuroimaging contributions to the understanding of discourse processes. In: TRAXLER, M.; GERNSBACHER, M. A. (Ed.). Handbook of Psycholinguistics. Amsterdam: Elsevier, 2006, p. 765-799.

MCCLELLAND, J. L.; CLEEREMANS, A. Connectionist Models. In: BYRNE, T.; CLEEREMANS, A.; WILKEN, P. (Ed.). Oxford Companion to Consciousness. New York: Oxford University Press, 2009. p. 177-181.

MCCLELLAND, J. L.; ROGERS, T. T. The parallel distributed processing approach to semantic cognition. Nature Reviews Neuroscience, v. 4, p. 310-322, 2003.

MCCLELLAND, J. L.; ST. JOHN. M.; TARABAN, R. Sentence comprehension: a parallel distributed processing approach. Language and Cognitive Processes, v. 4, p. 287-335, 1989.

MCCLELLAND, J. L.; ELMAN, J. L. The TRACE Model of Speech Perception. Cognitive Psychology, v. 18, p. 1-86, 1986. 
MCCLELLAND, J. L.; RUMELHART, D. E. An interactive activation model of context effects in letter perception: Part 1. An account of basic findings. Psychological Review, v. 88, p. 375-407, 1981.

MEL'CUK, I. Semantics and the lexicon in modern linguistics. In: INTERNATIONAL CONFERENCE ON INTELLIGENT TEXT PROCESSING AND COMPUTATIONAL LINGUISTICS (CICLING), 1, 2000, Mexico City. Proceedings... Mexico: IPN Publishing House, 2000. p. 6-18.

MORTON, J.; PATTERSON, K. E. A new attempt at interpretation, or, an attempt at a new interpretation. In: COLTHEART, M.; PATTERSON, K. E.; MARSHALL, J. C. (Eds.). Deep dyslexia. London: Routledge and Kegan Paul, 1980. p. 91-118.

NORRIS, D. Shortlist: a connectionist model of continuous speech recognition. Cognition, v. 52, n. 3, p. 189-234, 1994.

PINKER, S. Words and Rules. Lingua, v. 106, p. 219-242, 1998.

PULVERMÜLLER, F. Words in the brain's language. Behavioral and Brain Sciences. v. 22, p. 253-279, 1999.

SAHIN, N. T.; PINKER, S; CASH, S. S.; SCHOMER, D.; HALGREN, E. Sequential Processing of Lexical, Grammatical, and Phonological Information Within Broca's Area. Science, v. 326, p. 445-449, 2009.

SAUSSURE, F. Curso de linguística geral. São Paulo, Cultrix, 1986. 278 p. SAXE, R. Why and how to study Theory of Mind with fMRI. Brain Research, v. 1079, p. 57-65, 2006.

SCHERER, L. C. Como os hemisférios cerebrais processam o discurso: evidências de estudos comportamentais e de neuroimagem. In: CAMPOS, J. C.; PEREIRA, V. W. (Org.). Linguagem e cognição: relações interdisciplinares. Porto Alegre: EDIPUCRS, 2009. p. 77-102.

SCHMIDT, G. L.; SEGER, C. A. Neural correlates of metaphor processing: the roles of figurativeness, familiarity and difficulty. Brain and Cognition, v. 71, p. 375-386, 2009.

SEIDENBERG, M. S. Language acquisition and use: learning and applying probabilistic constraints. Science, v. 275, p. 1599-1603, 1997.

SEIDENBERG, M. S.; MCCLELLAND. J. L. A distributed, developmental model of visual word recognition and naming. Psychological Review, v. 96, p. 523-568, 1989. 
SINGLETON, D. How integrated is the integrated mental lexicon? In: LENGYEL, Z., NAVRACSICS, J. (Ed.). Second language lexical processes: Applied Linguistic and Psycholinguistic perspectives. Multilingual Matters Ltd., 2007. p. 10-29.

SÖHNGEN, C. C. Conexões linguísticas. In: ROSSA, A; ROSSA, C. (Org.). Rumo à psicolingüistica conexionista. Porto Alegre: Edipucrs, 2004. p. 213-231.

SOUSA, L. B.; GABRIEL, S. Aprendendo palavras através da leitura. Santa Cruz do Sul: EDUNISC, 2011. 136 p.

TEICHMANN, M.; TURC, G.; NOGUES, M.; FERRIEUX, S.; DUBOIS, B. A mental lexicon without semantics. Neurology, v. 79, n. 6, p. 1-2, 2012.

TEIXEIRA, J. F. Mentes e máquinas: uma introdução à ciência cognitiva. Porto Alegre: Artes Médicas, 1998. 182 p.

TOMASELLO, M. First verbs: a case study of early grammatical development. Cambridge: Cambridge University Press, 1992. 373 p.

ULLMAN, M. T. The biocognition of the mental lexicon. In: GASKELL, M. G. (Ed.). The Oxford Handbook of Psycholinguistics. Oxford, UK: Oxford University Press, 2007. p. 267-286.

ULLMAN, M. T.; PANCHEVA, R.; LOVE, T.; YEE, E.; SWINNEY, E.; HICKOCK, G. Neural correlates of lexicon and grammar: Evidence from the production, reading, and judgment of inflection in aphasia. Brain and Language, v. 93, p. 185-238, 2005.

ULLMAN, M. T. Contributions of memory circuits to language: the declarative / procedural model. Cognition, v. 92, n. 23, p. 1-70, 2004.

ULLMAN, M. T.; CORKIN, S.; COPPOLA, M.; HICKOK, G.; GROWDON, J. H.; KOROSHETZ, W. J.; PINKER, S. A neural dissociation within language: evidence that the mental dictionary is part of declarative memory, and that grammatical rules are processed by the procedural system. Journal of Cognitive Neuroscience, v. 9, p. 266-276, 1997.

VYGOTSKY, L. S. A construção do pensamento e da linguagem. São Paulo: Martins Fontes, 2001. 520 p. 
